\title{
The link between socioeconomic position, access to cycling infrastructure and cycling participation rates: an ecological study in Melbourne, Australia
}

\author{
Chance Pistoll ${ }^{\mathrm{a}}$, Anna Goodman ${ }^{\mathrm{b}}$
}

${ }^{a}$ The Royal Melbourne Hospital, Melbourne, Victoria, Australia.

${ }^{\mathrm{b}}$ Faculty of Epidemiology and Population Health, London School of Hygiene and Tropical Medicine, London, UK.

Corresponding author:

Chance Pistoll: The Royal Melbourne Hospital, Melbourne Health, 300 Grattan Street, Parkville VIC 3050, Australia. Chance.Pistoll@mh.org.au, +61420388385

Note: this is a personal version, created by Anna Goodman, of the text of the accepted journal article. It reflects all changes made in the peer review process, but does not incorporate any minor modifications made at the proof stage. The complete citation for the final journal article is:

- Pistoll, C. \& Goodman, A. 2014. The link between socioeconomic position, access to cycling infrastructure and cycling participation rates: an ecological study in Melbourne, Australia. Journal of Transport and Health, 1, 251-259.

- DOI: 10.1016/j.jth.2014.09.011

Copyright (C) and Moral Rights for this paper are retained by the individual authors and/or other copyright owners 


\section{$\underline{\text { Abstract }}$}

Objective: Promoting cycling has moved up the policy agenda in recent years, but debate still exists surrounding the role played by socioeconomic barriers to participation in low cycling countries. This ecological study aimed to examine whether there are systematic socioeconomic disparities in access to cycling infrastructure and investment in Melbourne, Australia.

Methods: We used Geographic Information System (GIS) techniques to measure the density of on-road, off-road and informal cycling routes in 58 neighbourhoods of inner Melbourne. We examined whether small-area socioeconomic indicators were associated with the density of these three types of cycling infrastructure or with local government spending on cycling. We additionally examined how small-area socio-economic position and infrastructure density were associated with the prevalence of cycling to work in the 2011 census.

Results: The density of on- and off-road cycling infrastructure was positively associated with cycle modal share (both $\mathrm{p}<0.0001$ ), and there was no evidence that the strength of this association differed between the two infrastructure types. The density of informal routes was not associated with cycling to work. There was no evidence that small-area socioeconomic position was systematically associated with the presence of on-road or quiet roads cycling infrastructure or with levels of investment. Levels of off-road infrastructure were somewhat higher in richer areas $(\mathrm{r}=0.32, \mathrm{p}=0.02)$, although much of this was located in parkland and may have a predominant recreational function.

Conclusion: In Melbourne, cycling infrastructure is positively correlated with cycle prevalence and is generally distributed equitably with respect to area-level socioeconomic position. In part this reflects the high levels of cycling infrastructure and spending in some relatively disadvantaged areas. Further studies that seek to understand the drivers behind successful policies in these areas may provide lessons for other areas, and aid our understanding of the complex relationships between cycling infrastructure, cycling behavior and socioeconomic position.

Keywords: cycling prevalence; cycling infrastructure; socioeconomic position; health policy.

\section{Highlights}

1. Local densities of cycling infrastructure in Melbourne predict cycle modal share.

2. Richer areas have more off-road cycle paths, but not more on-road cycle lanes

3. Even among poorer areas, some enjoy much better infrastructure and funding than others

4. The successful local cycling policies in these areas may hold valuable wider lessons. 


\section{Introduction}

A large and growing body of evidence indicates that regular commuter cycling is beneficial to the health of individuals and populations (Woodcock et al., 2011, Bassett et al., 2008, de Hartog et al., 2010, Huy et al., 2008, Pucher et al., 2010a, Saunders, 2013, Shephard, 2008). Cycling for active transportation is associated with significantly reduced rates of obesity (Gordon-Larsen et al., 2009), type 2 diabetes, hypertension (Furie and Desai, 2012) and perhaps all-cause mortality (de Hartog et al., 2010, Sahlqvist et al., 2013). Furthermore, the physical activity benefits of regular cycling appear at a population level to outweigh potential risks such as road traffic injury and exposure to air pollution (Rojas-Rueda, 2011, de Hartog et al., 2010, Woodcock J., 2014).

Recent years have seen a rise in cycling-related policies at many institutional levels (Ogilvie et al., 2011, Gotschi, 2011, Lindsay et al., 2011, Rojas-Rueda, 2011, Woodcock et al., 2009). This interest not only reflects the health benefits of cycling, but its potential to offer solutions to problems such as climate change, congestion, noise and air pollution and economic development. In the Australian Federal context, policies include the Australian Department of Health's 'Healthy Spaces and Places' program (Australian Department of Health, 2010), and the updated Active Transportation Policy of the federal Department of Infrastructure and Transport (Australian Department of Infrastructure, 2013). Victoria state level examples include the Cycling into the Future Policy of the Victorian Department of Transport (Victoria Department of Transport, 2012a) and the Sustainable and Active Transport Policy of the Victorian Department of Health (Victoria Department of Health, 2013). Local Melbourne examples include the City of Melbourne's Bike Plan (City of Melbourne, 2012) and the City of Yarra's Bicycle Strategy (City of Yarra, 2010).

Despite this policy interest, much debate exists about how best to increase cycling levels in low cycling countries. One recent research focus concerns the role of cycling infrastructure in supporting increased cycling rates. Although some causal effect of infrastructure upon cycling participation rates is probable, reliance on cross-sectional studies, small before-and-after studies and stated preference surveys means that the underlying evidence base is relatively weak (Fraser and Lock, 2011, Pucher et al., 2010b, Yang et al., 2010). The historical origins of cycling policy in Melbourne may offer an unusual opportunity to contribute to this debate. Construction of much of Melbourne's cycling infrastructure began in the 1990's in response to largely top-down policy decisions at the state level, reflecting state-wide economic, transport and environmental concerns (Goodman, 2008, Pucher et al., 2011). At the time when this new infrastructure was being created, cycling rates were at their lowest recorded levels $(0.8 \%$ commute prevalence in greater metropolitan Melbourne in 1996), but have since steadily increased (to $1.6 \%$ in 2011, (Australian Bureau of Statistics, 2013b)). This policy backdrop may help to mitigate one traditional limitation of cross-sectional studies in this field, by providing some macro-level evidence that the extension of cycling infrastructure in the city occurred prior to any increases in cycling prevalence and was largely prompted by external considerations rather than local demand. The diversity of types of cycling 
infrastructure created in Melbourne also offers the potential to contribute to debates regarding the relative importance of on-road versus off-road cycling infrastructure (Dill, 2009, Pucher et al., 2010b).

Another recent focus of investigation has been the role that socioeconomic barriers may play in preventing an equitable uptake of cycling. In countries with low modal shares such as the UK and Australia, evidence suggests that recent modest growth in cycling has tended to occur disproportionately amongst socioeconomically advantaged groups (Goodman, 2013, Kamphuis et al., 2008, Sahlqvist and Heesch, 2012, Steinbach et al., 2011). Evidence from Melbourne seems to confirm this finding. An analysis of census data from 1996-2006 found that the fastest growth in commuter cycling rates occurred among commuters with higher educational qualifications, higher income and working in white-collar occupations (Victoria Department of Transport, 2008). One possible mechanism for such an effect could involve greater investment in cycling facilities in socioeconomically advantaged areas. To our knowledge, only two studies (both from the USA) have explicitly sought to investigate relationships between socioeconomic position and proximity to cycling infrastructure. The first of these was an ecological study that examined the socioeconomic distribution of cycling infrastructure in New Jersey. This study concluded that infrastructure location was not inequitably situated in that state (Deka and Connelly, 2011). The second involved an equity analysis of cycling infrastructure in Portland, Oregon. This study found that cycle routes were more likely to be located in low socioeconomic areas, but less likely to be located near areas with high proportions of ethnic minorities, the elderly and youths (Dill and Haggerty, 2009). These mixed findings suggest a complex and context specific interaction between policymaking, the physical environment and socioeconomic indicators.

This paper seeks to contribute to this research literature in two ways. Firstly, it aims to examine the relationship between cycling infrastructure density and cycling prevalence in Melbourne, Australia. Secondly, it aims to establish whether there are systematic arealevel socioeconomic differences with respect to access to cycling infrastructure and investment. Through addressing these aims, this paper intends to examine whether in Melbourne any inequalities in access to cycling infrastructure and investment exist that are likely to lead to inequalities in cycling participation.

\section{$\underline{\text { 2. Materials and Methods }}$}

\subsection{Setting}

The study area was inner Melbourne, the urban centre of the capital of Victoria, Australia, with a population of around 700,000 (Australian Bureau of Statistics, 2013b). Inner Melbourne comprises a high-density, mixed-use core, surrounded by significant urban sprawl, and bounded by rivers on three sides (Supplementary Figure S1). The city is flat with a mild oceanic climate creating ideal conditions for year round cycling (Pucher et al., 2011). Inner Melbourne is one of the highest-cycling regions in Australia (Australian Bureau of Statistics, 2013b). 
Cycling policy and governance in Melbourne is fragmented. State government is concerned with strategy, acting primarily through the Department of Transportation. Promoting cycling through local investment, construction, by-laws and other programs is largely the responsibility of Local Government Authorities (LGA's), of which there are 17 in inner and middle Melbourne. Parks Victoria has significant oversight of development in green zones. This policy fragmentation has contributed to a variable quantity and quality of cycling infrastructure across inner Melbourne, with marked differences between LGA's in the extent of infrastructure provided, and in the relative balance between on- and off-road routes.

\subsection{Geographical units of analysis and study area}

Most analyses were conducted at the 'Statistical area 2' (Sa2) level; these are census units with a population of around 10,000 individuals, reflecting communities that interact together socially and economically (Australian Bureau of Statistics, 2012b). Assuming the majority of cycle commuting converges on the Central Business District (CBD), we defined the study area as Sa2's with a centroid within $10 \mathrm{~km}$ of the geographical centre of the CBD (Supplementary Figures S1 and S2). This distance approximates what is traditionally referred to as 'inner Melbourne', and ensured a relatively homogenous set of urban areas for comparison. In addition to excluding areas further than $10 \mathrm{~km}$ from the CBD, we also excluded two additional Sa2's, Port Melbourne Industrial Area and Flemington Racecourse - both special economic areas with very low permanent populations. This resulted in $58 \mathrm{Sa} 2$ 's in our analysis (mean size $4.2 \mathrm{~km}^{2}$, mean commuter population 10,059 individuals, average commuter age 37.1 years).

$\mathrm{Sa} 2$ analyses were in a few instances complemented by analyses at the LGA level. LGA's reflect local government divisions within Australia, with an average population of 135,000 (Australian Bureau of Statistics, 2012a).

Ethical approval was not required as all data were fully in the public domain.

\subsection{Measure of small-area socioeconomic position}

Small-area socioeconomic position was measured using the 2011 Australian Bureau of Statistics 'Socioeconomic Indicators For Areas' (SEIFA). We used an indicator that measures relative advantage and disadvantage based upon a multidimensional framework of income, education, employment, occupation and household variables (Australian Bureau of Statistics, 2013c). Scores were defined with reference to Victoria as a whole.

\subsection{Measure of density of cycle facilities}

Cycling infrastructure location was identified through the Victorian Department of Transportation, in the form of TravelSmart map ArcGIS shape files. TravelSmart was a state government program that aimed to raise awareness about the availability of active and sustainable transport options. One key initiative involved the production of maps detailing the type and position of cycling infrastructure (Victoria Department of 
Transport, 2012b). These maps were produced in 2012 to cover all of Melbourne by synthesising individual LGA level maps created between 2008 and 2011.

The maps distinguished three types of cycling infrastructure (see Supplementary Figure S3 for illustrated photographs):

1. On-road cycle lanes: Visibly delineated space for cyclists on existing roads, incorporating a painted median strip with a suggested minimum width of 1.5 metres and a painted bicycle symbol.

2. Off-road cycle paths: Physically separated spaces for cyclists from motorised traffic. They can be on existing road surface with a physical barrier, or for example through parks and gardens. In Melbourne, a large number are shared with pedestrians.

3. Quiet roads: Spaces shared by motor vehicles and bicycles with no separation. They are generally identified as being low traffic volume and may not incorporate any specific cycling signage or traffic calming measures.

We calculated the total length of each of these three types of infrastructure within each $\mathrm{Sa} 2(\mathrm{~km})$, and divided these by the size of each Sa2 $\left(\mathrm{km}^{2}\right)$. This density variable represents the relative opportunities for residents to access different types of infrastructure in their local areas, and provides an estimate of the visibility of cycling as a means of transportation.

\subsection{Measure of investment in cycling}

Local government spending was obtained via the annual Bicycle Expenditure Index (BiXE), compiled from LGA budgets by the cycling advocacy group Bicycle Network (Bicycle Network, 2013). BiXE scores (in dollars per resident) were averaged from the years 2006-2012 for inner and middle LGA's, providing an estimate of medium-term investment in cycling. 17 LGA's comprising inner $(\mathrm{N}=5)$ and middle Melbourne $(\mathrm{N}=12)$ were included in the analysis (See Supplementary Figure S2 for examples of LGA's). Due to large geographical and contextual differences, outer Melbourne LGA's were excluded.

\subsection{Measure of cycle commute modal share}

Our measure of commute modal share came from the 2011 Australian census, a compulsory household survey with a response rate of $96.3 \%$ (Australian Bureau of Statistics, 2013a). For each participant in work and aged greater than 15 the census asked: 'how did this person get to work on $9^{\text {th }}$ August 2011?' (Australian Bureau of Statistics, 2013a). From this question we calculated the proportion of all commuters that cycle to work in each Sa2, overall and stratified by gender. The census did not include multi-modal response options for cycling, meaning we will not have captured some individuals combining cycling with another mode (e.g. public transport). 


\subsection{Statistical analyses}

After presenting scatter graphs and correlation coefficients, we fit multivariable linear regression models with Sa2's as the unit of analysis. In these models, predictor variables were entered as linear terms unless adding a quadratic term provided evidence $(p<0.05)$ of non-linearity. We adjusted all models for distance between the Sa2 centroid and the CBD. When examining predictors of commuter cycling prevalence, we log-transformed our measure of cycling prevalence because it was positively skewed. For ease of interpretation, the resulting regression coefficients were exponentiated to create a measure of relative percentage change using the formula: $(100 * \exp (\boldsymbol{\beta})-1)$. When comparing the magnitude of different predictor variables (e.g. the strength of association with on- and off-road infrastructure) we used the lincom command. All analyses used Stata 12. Maps were created in ArcGIS 10.

\section{$\underline{\text { 3. Results }}$}

\subsection{Marked geographical variation in the prevalence of cycling to work, in small- area socio-economic position and cycling infrastructure density}

The percentage of commuters who cycled in the study area was $4.4 \%$, ranging from $12.6 \%$ in Fitzroy North (LGA of Yarra) to $1.4 \%$ in Essendon (LGA of Moonee Valley) (Supplementary Figure S4). 5.7\% of males cycled while only $3.0 \%$ of females cycled ( $\mathrm{p}<0.0001$ for difference), although the proportion of female cyclists was higher in areas where cycling was more common overall (Figure 1).

Figure 1: Association between the prevalence of cycling to work and the proportion of female cyclists in inner Melbourne

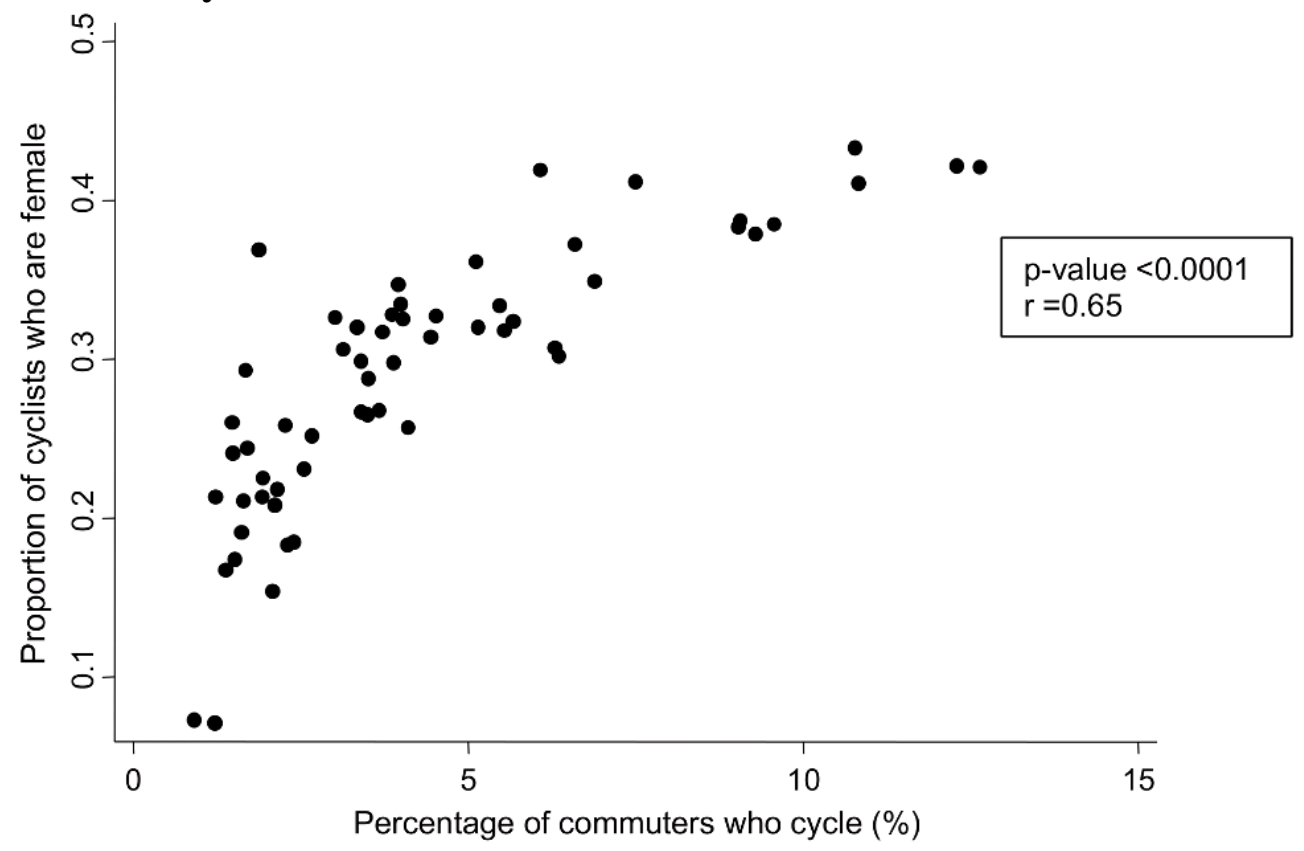

Units of analysis are $58 \mathrm{Sa} 2$ areas in inner Melbourne. Box shows Pearson correlation coefficients and associated p-values 
There was considerable geographic variation in small-area socioeconomic position across our study area, although the affluence of inner Melbourne compared to the rest of Victoria meant that most areas were still above the state median. The most affluent areas were found to the south of the CBD and in the outer Eastern parts of the study area, while the most deprived areas were to the north and west (Supplementary Figure S5). There was also considerable variation in the density of all three types of infrastructure across the Sa2's in the study area, including a small number of Sa2's with exceptionally high levels of on-road infrastructure (Supplementary Figure S6). Both on- and off-road infrastructure densities tended to reduce with greater distance from the CBD, but remained comparatively high in the north and northeast relative to the outer east and west. Quiet road densities were highest in the outer eastern areas.

\subsection{Cycling modal share in relation to socioeconomic position and infrastructure density}

In univariable analyses the percentage of commuters who cycled was significantly correlated with density of on-road and, to a lesser extent, off-road infrastructure (Figure 2). After controlling for distance to centre and socioeconomic position, each $\mathrm{km} / \mathrm{km}^{2}$ increase in on-road cycle lanes was associated with a $39 \%$ relative increase in the number of commuters who cycled. Each $\mathrm{km} / \mathrm{km}^{2}$ increase in off-road cycle paths was associated with a $40 \%$ relative increase in the number of commuters who cycled (Table 1). There was no evidence of a difference in the magnitude of the association with on-road versus off-road infrastructure either before $(\mathrm{p}=0.26)$ or after $(\mathrm{p}=0.94)$ adjustment. There was no evidence that the density of quiet roads was correlated with the percentage of commuters who cycled, either before $(\mathrm{p}=0.64)$ or after controlling for confounders $(\mathrm{p}=0.15)$. Findings were similar between males and females, with a non-significant trend towards slightly stronger associations between infrastructure density and female cycling participation (Table 1). 
Figure 2: Scatter plot of cycling infrastructure density in inner Melbourne and the percentage of commuters who cycle
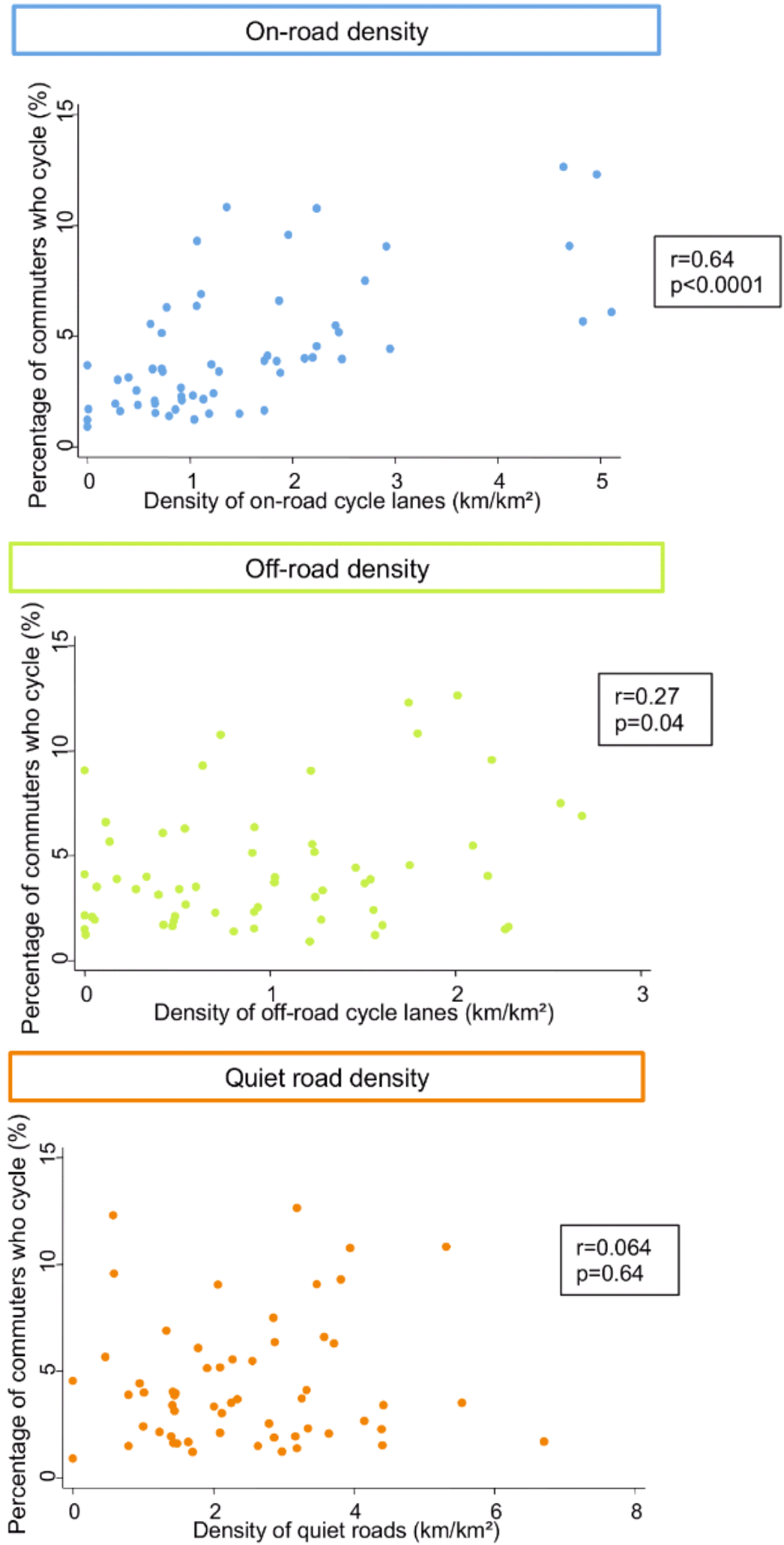

Units of analysis are $58 \mathrm{Sa} 2$ areas in inner Melbourne. Box shows Pearson correlation coefficients and associated p-values 
Table 1: Relative percentage change in commuter cycling prevalence across $58 \mathrm{Sa} 2$ areas in inner Melbourne

\begin{tabular}{|c|c|c|c|c|c|c|c|c|}
\hline & \multirow{3}{*}{$\begin{array}{l}\text { No. } \\
\text { Sa2's }\end{array}$} & \multicolumn{6}{|c|}{ Relative percentage change in total cycle modal share: percent $(95 \%$ CI $)$} \\
\hline & & & \multicolumn{2}{|c|}{ Total Population } & \multicolumn{2}{|c|}{ Male } & \multicolumn{2}{|c|}{ Female } \\
\hline & & & Univariable & Adjusted & Univariable & Adjusted & Univariable & Adjusted \\
\hline \multicolumn{2}{|c|}{$\begin{array}{l}\text { On-road cycle lanes: change per } \\
\mathbf{k m} / \mathbf{k m}^{2} \text { increase }\end{array}$} & & $\begin{array}{c}38 \\
(24,54)\end{array}$ & $\begin{array}{l}39 \\
(25,54)\end{array}$ & $\begin{array}{c}33 \\
(20,47)\end{array}$ & $\begin{array}{c}37 \\
(24,51)\end{array}$ & $\begin{array}{c}57 \\
(36,83)\end{array}$ & $\begin{array}{c}50 \\
(30,73)\end{array}$ \\
\hline \multicolumn{2}{|c|}{$\begin{array}{l}\text { Off-road cycle lanes: change per } \\
\mathbf{k m} / \mathbf{k m}^{2} \text { increase }\end{array}$} & & $\begin{array}{c}22 \\
(-4,54)\end{array}$ & $\begin{array}{c}40 \\
(17,67)\end{array}$ & $\begin{array}{c}19 \\
(-4,47)\end{array}$ & $\begin{array}{c}37 \\
(15,63)\end{array}$ & $\begin{array}{c}29 \\
(-7,78)\end{array}$ & $\begin{array}{c}51 \\
(18,93)\end{array}$ \\
\hline \multicolumn{2}{|c|}{$\begin{array}{l}\text { Quiet roads: change per } \mathrm{km} / \mathrm{km}^{2} \\
\text { increase }\end{array}$} & & $\begin{array}{c}2 \\
(-10,16)\end{array}$ & $\begin{array}{c}6 \\
(-2,16)\end{array}$ & $\begin{array}{c}3 \\
(-8,16)\end{array}$ & $\begin{array}{c}7 \\
(-1,17)\end{array}$ & $\begin{array}{c}1 \\
(-15,20)\end{array}$ & $\begin{array}{c}7 \\
(-5,20)\end{array}$ \\
\hline \multirow{4}{*}{$\begin{array}{l}\text { Small-area } \\
\text { socioeconomic } \\
\text { position } \\
\left(50^{\text {th }}-75^{\text {th }}\right. \\
\text { percentile } \\
\text { baseline })\end{array}$} & $\begin{array}{l}0-50^{\text {th }} \\
\text { percentile }\end{array}$ & 9 & $\begin{array}{c}-9 \\
(-48,60)\end{array}$ & $\begin{array}{l}-9 \\
(-36,30)\end{array}$ & $\begin{array}{c}-14 \\
(-48,44)\end{array}$ & $\begin{array}{c}-15 \\
(-40,19)\end{array}$ & $\begin{array}{c}0 \\
(-54,117)\end{array}$ & $\begin{array}{c}5 \\
(-35,71)\end{array}$ \\
\hline & $\begin{array}{l}50^{\text {th }}-75^{\text {th }} \\
\text { percentile }\end{array}$ & 13 & 0 & 0 & 0 & 0 & 0 & 0 \\
\hline & $\begin{array}{l}75^{\text {th }}-90^{\text {th }} \\
\text { percentile }\end{array}$ & 19 & $\begin{array}{c}-21 \\
(-50,26)\end{array}$ & $\begin{array}{c}-33 \\
(-51,-8)\end{array}$ & $\begin{array}{c}-16 \\
(-45,28)\end{array}$ & $\begin{array}{c}-30 \\
(-49,-5)\end{array}$ & $\begin{array}{c}-34 \\
(-65,26)\end{array}$ & $\begin{array}{c}-42 \\
(-63,-11)\end{array}$ \\
\hline & $\begin{array}{l}90^{\text {th }}-100^{\text {th }} \\
\text { percentile }\end{array}$ & 17 & $\begin{array}{c}-42 \\
(-64,-7)\end{array}$ & $\begin{array}{c}-43 \\
(-58,-22)\end{array}$ & $\begin{array}{c}-40 \\
(-61,-7)\end{array}$ & $\begin{array}{c}-41 \\
(-56,-20)\end{array}$ & $\begin{array}{c}-51 \\
(-75,-5)\end{array}$ & $\begin{array}{c}-51 \\
(-68,-24)\end{array}$ \\
\hline \multirow{5}{*}{$\begin{array}{l}\text { Distance to } \\
\text { centre } \\
(2-4 \mathrm{~km} \text { baseline })\end{array}$} & $0-2 \mathrm{~km}$ & 5 & $\begin{array}{c}-35 \\
(-64,17)\end{array}$ & $\begin{array}{c}-38 \\
(-59,-5)\end{array}$ & $\begin{array}{c}-33 \\
(-62,18)\end{array}$ & $\begin{array}{c}-35 \\
(-56,-2)\end{array}$ & $\begin{array}{c}-37 \\
(-71,37)\end{array}$ & $\begin{array}{c}-42 \\
(-67,3)\end{array}$ \\
\hline & $2-4 \mathrm{~km}$ & 13 & 0 & 0 & 0 & 0 & 0 & 0 \\
\hline & $4-6 \mathrm{~km}$ & 12 & $\begin{array}{c}5 \\
(-33,65)\end{array}$ & $\begin{array}{c}47 \\
(4,109)\end{array}$ & $\begin{array}{c}6 \\
(-31,63)\end{array}$ & $\begin{array}{c}44 \\
(3,102)\end{array}$ & $\begin{array}{c}9 \\
(-40,99)\end{array}$ & $\begin{array}{c}69 \\
(5,174)\end{array}$ \\
\hline & $6-8 \mathrm{~km}$ & 14 & $\begin{array}{c}-31 \\
(-56,6)\end{array}$ & $\begin{array}{c}26 \\
(-12,79)\end{array}$ & $\begin{array}{c}-22 \\
(-48,18)\end{array}$ & $\begin{array}{c}34 \\
(-5,89)\end{array}$ & $\begin{array}{c}-46 \\
(-70,-4)\end{array}$ & $\begin{array}{c}19 \\
(-27,94)\end{array}$ \\
\hline & $8-10 \mathrm{~km}$ & 14 & $\begin{array}{c}-60 \\
(-74,-39)\end{array}$ & $\begin{array}{l}-19 \\
(-44,19)\end{array}$ & $\begin{array}{c}-53 \\
(-69,-29)\end{array}$ & $\begin{array}{c}-6 \\
(-35,35)\end{array}$ & $\begin{array}{c}-75 \\
(-86,-55)\end{array}$ & $\begin{array}{c}-39 \\
(-64,2)\end{array}$ \\
\hline
\end{tabular}

$\mathrm{CI}=$ confidence interval, $\mathrm{km}=$ kilometres. Values in bold are significant (for linear terms)/significantly different from the reference category (for categorical variables), at $\mathrm{p}<0.05$. Adjusted analyses adjust for all variables in the column. Percentiles for small-area socioeconomic position defined relative to Victoria State as a whole

Table 1 also shows the prevalence of commuter cycling was lower in the most socioeconomically advantaged areas. Specifically cycling prevalence in the top two socioeconomic categories was 33\% ( $\mathrm{p}=0.014)$ and $43 \%(\mathrm{p}=0.001)$ lower than in the reference group in adjusted analyses. Again, similar results were observed in males and females. 


\subsection{Socioeconomic position, infrastructure density and local government investment}

In univariable models we found some evidence that densities of off-road infrastructure were somewhat higher in more affluent areas ( $\mathrm{r}=0.32, \mathrm{p}=0.02$; see Figure 3 ). This was subsequently confirmed in multivariable analyses (Table 2). Compared to the reference group, those areas in the $75-90^{\text {th }}$ socioeconomic percentile had on average $0.79 \mathrm{~km} / \mathrm{km}^{2}$ more off-road cycle infrastructure density after controlling for confounding variables $(\mathrm{p}=0.002)$, and those in the $90-100^{\text {th }}$ percentiles had $0.72 \mathrm{~km} / \mathrm{km}^{2}$ more $(\mathrm{p}=0.004)$. There was no evidence of systematic socioeconomic differences in on-road or quiet road infrastructure in either univariable or multivariable analyses.

Figure 3: Scatter plots of socioeconomic position, infrastructure density and local government spending
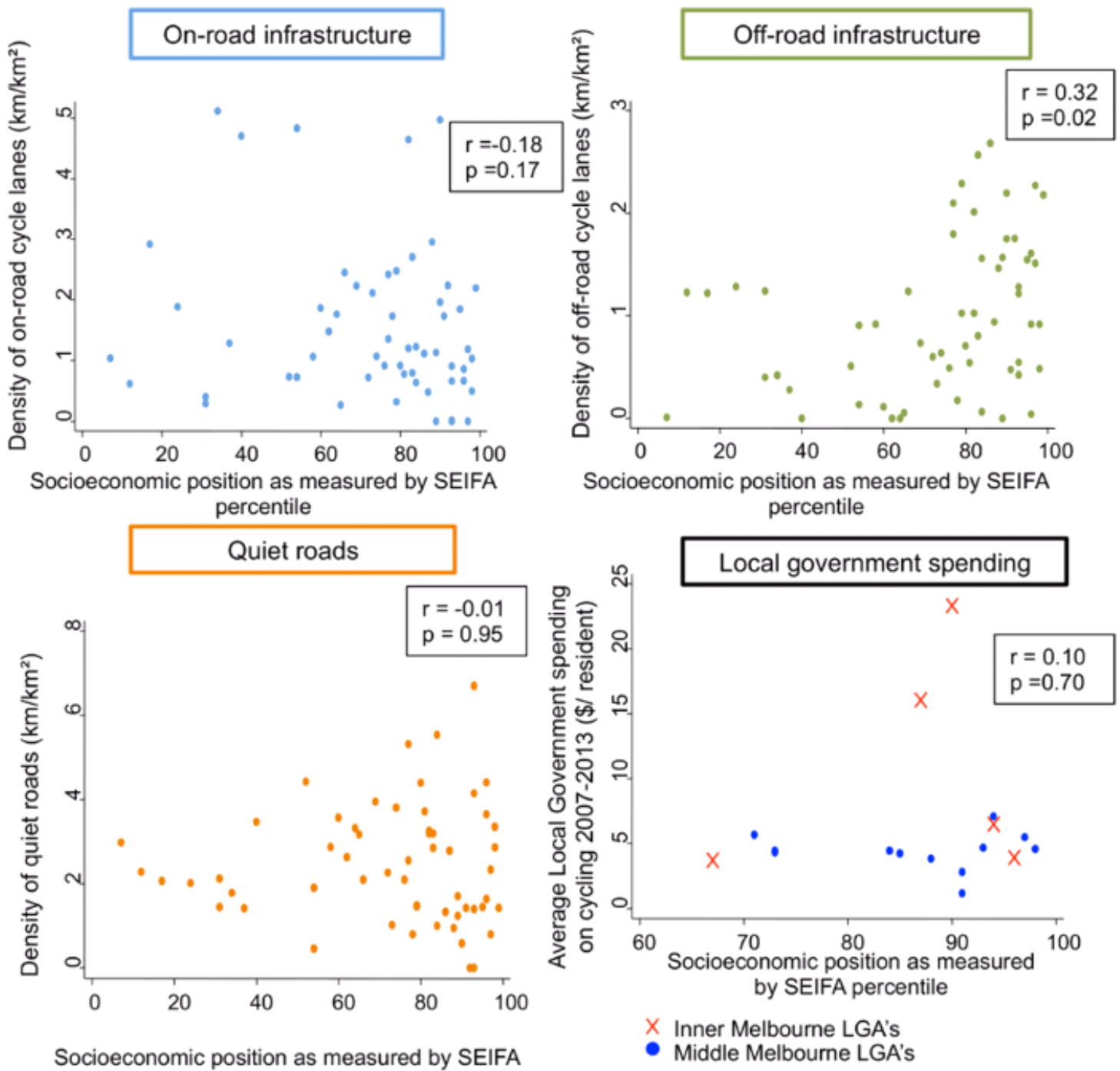

Socioeconomic position as measured by SEIFA percentile

Units of analysis are $58 \mathrm{Sa} 2$ areas in inner Melbourne for infrastructure density plots. Units of analysis are 17 LGA's in inner and middle Melbourne for spending plot. Boxes show Pearson correlation coefficients and associated p-values. SEIFA= Socioeconomic Indicators For Areas, percentiles defined relative to Victoria State as a whole. 
Table 2: Socioeconomic distribution of cycling infrastructure across $58 \mathrm{Sa} 2$ areas in inner Melbourne

\begin{tabular}{|c|c|c|c|c|c|c|c|c|}
\hline & \multirow{3}{*}{$\begin{array}{c}\text { No. } \\
\text { Sa2's }\end{array}$} & \multicolumn{6}{|c|}{ Change in infrastructure density $\left(\mathrm{km} / \mathrm{km}^{2}\right)(95 \% \mathrm{CI})$} \\
\hline & & & \multicolumn{2}{|c|}{ On-road cycle lane density } & \multicolumn{2}{|c|}{ Off-road cycle lane density } & \multicolumn{2}{|c|}{ Quiet roads density } \\
\hline & & & Univariable & Adjusted & Univariable & Adjusted & Univariable & Adjusted \\
\hline \multirow{4}{*}{$\begin{array}{l}\text { Small-area } \\
\text { socio- } \\
\text { economic } \\
\text { position }\end{array}$} & $\begin{array}{l}0-50^{\text {th }} \\
\text { percentile }\end{array}$ & 9 & $\begin{array}{c}0.39 \\
(-0.73,1.51)\end{array}$ & $\begin{array}{c}0.62 \\
(-0.34,1.59)\end{array}$ & $\begin{array}{c}0.20 \\
(-0.39,0.79)\end{array}$ & $\begin{array}{c}0.14 \\
(-0.43,0.72)\end{array}$ & $\begin{array}{c}-0.56 \\
(-1.80,0.68)\end{array}$ & $\begin{array}{c}-0.20 \\
(-1.41,1.01)\end{array}$ \\
\hline & $\begin{array}{l}50^{\text {th }}-75^{\text {th }} \\
\text { percentile }\end{array}$ & 13 & 0 & 0 & 0 & 0 & 0 & 0 \\
\hline & $\begin{array}{l}75^{\text {th }}-90^{\text {th }} \\
\text { percentile }\end{array}$ & 19 & $\begin{array}{c}-0.18 \\
(-1.11,0.75)\end{array}$ & $\begin{array}{c}0.18 \\
(-0.62,0.97)\end{array}$ & $\begin{array}{c}0.78 \\
(0.29,1.27)\end{array}$ & $\begin{array}{c}0.79 \\
(0.32,1.27)\end{array}$ & $\begin{array}{c}-0.16 \\
(-1.19,0.87)\end{array}$ & $\begin{array}{c}-0.08 \\
(-1.07,0.92)\end{array}$ \\
\hline & $\begin{array}{l}90^{\text {th }}-100^{\text {th }} \\
\text { percentile }\end{array}$ & 17 & $\begin{array}{c}-0.38 \\
(-1.33,0.57)\end{array}$ & $\begin{array}{c}-0.41 \\
(-1.21,0.38)\end{array}$ & $\begin{array}{c}0.77 \\
(0.27,1.26)\end{array}$ & $\begin{array}{c}0.72 \\
(0.24,1.19)\end{array}$ & $\begin{array}{c}-0.57 \\
(-1.62,0.48)\end{array}$ & $\begin{array}{c}-0.31 \\
(-1.32,0.69)\end{array}$ \\
\hline \multirow[t]{5}{*}{$\begin{array}{l}\text { Distance to } \\
\text { centre }\end{array}$} & $0-2 \mathrm{~km}$ & 5 & $\begin{array}{c}0.47 \\
(-0.68,1.61)\end{array}$ & $\begin{array}{c}0.50 \\
(-0.64,1.63)\end{array}$ & $\begin{array}{c}-0.66 \\
(-1.40,0.09)\end{array}$ & $\begin{array}{c}-0.43 \\
(-1.11,0.25)\end{array}$ & $\begin{array}{c}-0.11 \\
(-1.48,1.25)\end{array}$ & $\begin{array}{c}-0.12 \\
(-1.55,1.31)\end{array}$ \\
\hline & $2-4 \mathrm{~km}$ & 13 & 0 & 0 & 0 & 0 & 0 & 0 \\
\hline & $4-6 \mathrm{~km}$ & 12 & $\begin{array}{c}-1.05 \\
(-1.92,-0.18)\end{array}$ & $\begin{array}{c}-1.16 \\
(-2.02,-0.29)\end{array}$ & $\begin{array}{c}-0.60 \\
(-1.17,-0.03)\end{array}$ & $\begin{array}{c}-0.47 \\
(-0.98,0.05)\end{array}$ & $\begin{array}{c}1.55 \\
(0.51,2.59)\end{array}$ & $\begin{array}{c}1.49 \\
(0.41,2.57)\end{array}$ \\
\hline & $6-8 \mathrm{~km}$ & 14 & $\begin{array}{c}-1.30 \\
-2.13,-0.46)\end{array}$ & $\begin{array}{c}-1.22 \\
(-2.05,-0.39)\end{array}$ & $\begin{array}{c}-0.80 \\
(-1.35,-0.26)\end{array}$ & $\begin{array}{c}-0.80 \\
(-1.29,-0.31)\end{array}$ & $\begin{array}{c}1.28(0.28 \\
2.28)\end{array}$ & $\begin{array}{c}1.25 \\
(0.21,2.29)\end{array}$ \\
\hline & $8-10 \mathrm{~km}$ & 14 & $\begin{array}{c}-1.70 \\
(-2.53,-0.86)\end{array}$ & $\begin{array}{c}-1.87 \\
(-2.70,-1.04)\end{array}$ & $\begin{array}{c}-0.68 \\
(-1.22,-0.14)\end{array}$ & $\begin{array}{c}-0.67 \\
(-1.17,-0.18)\end{array}$ & $\begin{array}{c}0.42 \\
(-0.58,1.42)\end{array}$ & $\begin{array}{c}0.41 \\
(-0.64,1.45)\end{array}$ \\
\hline
\end{tabular}

$\mathrm{CI}=$ confidence interval, $\mathrm{km}=$ kilometers. Values in bold are significantly different from the reference category $(\mathrm{p}<0.05)$. Adjusted analyses adjust for all variables in the column. Percentiles for small-area socioeconomic position defined relative to Victoria State as a whole.

We found no evidence of systematic socioeconomic differences in levels of cycling investment (Figure 3). Once again, however, a small number of unusually pro-cycling areas were observed, with two inner Melbourne LGA's consistently investing comparatively large amounts in cycling. These were Yarra LGA (16.1 Australian dollars per resident) and Melbourne LGA (23.3 Australian dollars per resident), both LGAs of medium socioeconomic position and close to the CBD.

\section{Discussion}

In this ecological study, we found that in inner Melbourne the commute modal share of cycling is positively associated with the local density of on-road and of off-road cycling routes, but not quiet roads. The density of on-road infrastructure and quiet roads did not differ with respect to small-area socioeconomic position, but off-road routes were more common in the most affluent areas. By contrast, commuter cycling prevalence was highest in areas of middle-low socioeconomic position. Levels of local government spending on cycling were generally low, with a few notable exceptions of highinvestment areas. 


\subsection{Study limitations}

The cross-sectional design of our study makes it difficult to ascertain the direction of causality between the presence of cycling infrastructure and the prevalence of cycle commuting. We believe that this difficulty is partly offset by the fact that infrastructure development began in Melbourne when cycling rates were at an all-time low, and analysis of policy documents indicates that the investment appeared to be largely motivated by external state-wide policy considerations (Goodman, 2008, Pucher et al., 2011). Nevertheless, decisions about where specifically to build new infrastructure within Melbourne may have been partly driven by pre-existing demand from within the local population. One way to overcome this limitation would be to interview key policy makers regarding these historical decisions. This would be a valuable direction for future research, ideally as part of a broader program of work seeking to understand why some parts of Melbourne have come to enjoy much higher investment levels than others.

A second key limitation concerns our use of area-level data. Although we found little evidence of systematic socioeconomic inequalities in relation to access to cycling infrastructure at the level of Sa2s, we cannot be sure that inequalities do not exist at an individual level. This point may have particular relevance in relation to the increasing numbers of comparatively affluent young professionals currently moving into traditionally poorer areas of the inner North of Melbourne. In the course of this gentrification process, it is possible that immigrating professionals preferentially settle in those areas of a given $\mathrm{Sa} 2$ that are particularly well served by cycling infrastructure.

A third important limitation concerns our lack of information regarding the quality of cycling infrastructure. Our models assumed a uniform quality of cycling infrastructure, but in reality this assumption is almost certainly not true. The presence of some poor quality infrastructure could potentially reduce the strength of associations between cycling infrastructure and cycling prevalence, and hide socioeconomic inequalities in access to high-quality cycling infrastructure. Measuring infrastructure quality would therefore be one useful direction for future research. Another useful extension would be to explore the circumstances under which the presence of infrastructure affects travel behavior - for example, by investigating the maximum acceptable route deviation to use infrastructure of different types or quality. Such research might ideally combine a range of methodologies, including qualitative interviews with cyclists and GIS techniques to map the flow of bicycles through space.

As census data were used in this study, we were restricted to commuting as an outcome and could not address other forms of cycling such as travel to non-employment locations or recreation. Nonetheless, recent evidence from the UK suggests that the prevalence of cycling to work and the proportion of all trips made by bicycle generally correlate well at the population level (Goodman, 2013).

It is also possible that the associations observed were influenced by a number of potential confounders for which we were not able to control, such as traffic calming measures and local cycling advocacy. Finally, this study was limited to inner Melbourne, so we cannot 
be certain that the relationships are generalisable to greater metropolitan Melbourne or other cities.

\subsection{Implications of the study with respect to cycling infrastructure and cycle modal share}

To our knowledge, this is the first study to demonstrate correlation between increasing on-road and off-road infrastructure density and increasing commute modal share in Melbourne, Australia. While these results are consistent with other ecological studies (Dill et al., 2003, Buehler and Pucher, 2012, Krizek et al., 2009), their replication in a new geographical context adds to the generalisability of this phenomenon. This replication also suggests the relevance of our approach of using the local density of cycling infrastructure as a meaningful basis for assessing socioeconomic barriers to cycling participation. Nevertheless, as discussed elsewhere, more high quality prospective studies are needed to provide a robust assessment of the impact of building cycling infrastructure upon cycling behavior (Pucher et al., 2010b, Fraser and Lock, 2011, Yang et al., 2010, Goodman et al., 2014).

In contrast to other studies suggesting a cyclist preference for off-road cycling infrastructure (Pucher et al., 2010b, Broach et al., 2012, Caulfield et al., 2012), we found no evidence that on-road and off-road infrastructure differ in their apparent effectiveness in supporting cycling to work. Previous studies have suffered stated preference design (Caulfield et al., 2012) and selection bias (Broach et al., 2012), however there are also context specific factors in Melbourne that could plausibly explain this finding. The gridlike layout of much of inner Melbourne may mean that on-road infrastructure generally provides a more direct route than off-road paths, many of which meander or are in parkland. Furthermore, in LGA's such as Yarra with high densities of on-road infrastructure, many key backstreets have intersection barriers that only permit bicycle and pedestrian access, creating de-facto cycle highways (City of Yarra, 2010). While this situation is specific to Melbourne, more studies would benefit in establishing the circumstances under which on- vs. off-road cycle routes have stronger effects, as there are potential implications for both cost and safety.

The fact that no relationship was found between quiet roads and cycling prevalence may seem surprising at first. It is important, however, to emphasise that TravelSmart introduced the category of 'quiet roads' in the context of a marketing campaign to identify the best places to cycle even where designated infrastructure was not available. Thus while some areas with a high proportion of quiet roads may have had genuinely low levels of motorised traffic, others may simply have been areas where little formal cycling infrastructure was available. Our finding therefore does not undermine programs being conducted for example in Auckland, where modest increases in active travel and street activation have been observed with the introduction of traffic-calming 'self explanatory streets' (Woodward, 2013). 


\subsection{Implications of the study with respect to socioeconomic barriers to cycling participation}

We found some evidence that those in higher socioeconomic areas have increased access to off-road infrastructure. This is not in keeping with one previous study in New Jersey, which concluded that infrastructure placement in that state is equitable (Deka and Connelly, 2011). In Melbourne, a large amount of off-road infrastructure is located in parks, meaning this finding may be context specific if more affluent people are more likely to live closer to green spaces. Despite greater access to off-road routes, we found that commuters in the most affluent areas were in fact less likely to cycle to work than those in less affluent areas. We believe it that this paradox may partly reflect a tendency for off-road paths in high socioeconomic areas to be indirect routes in parkland rather than direct routes more suitable for commuting. It may also partly reflect the operation of other factors (e.g. car access) that reduce the prevalence of cycling in the most affluent areas, thereby highlighting that cycling infrastructure is by no means the only determinant of cycling behavior.

Importantly, we found no evidence for systematic socioeconomic differences in access to on-road infrastructure and no evidence for a difference between on- and off-road routes in the magnitude of their association with cycle commuting rates. This in a sense indicates an equity success for Melbourne. In this respect, access to high density, on-road cycling infrastructure is more of a 'postcode lottery' rather than a function of the socioeconomic position of ones area of residence. Similarly, we found no evidence of systematic socioeconomic differences in local government cycling spending, although generally investment levels were low except for a couple of standout LGA's.

\section{Conclusions and directions for future research}

The City of Yarra was one standout LGA that has adopted an integrated policy to promote cycling (City of Yarra, 2010). This has included establishing the highest density of on-road cycling lanes in Melbourne, introducing promotional programs and traffic calming measures, and making a sustained financial commitment to increase cycling. Yarra has within it some of the lowest socioeconomic areas in inner Melbourne but also enjoys some of the highest commuter cycling rates. The policy adopted by this municipality may represent an effective, cost-effective and equitable success that could be emulated by other LGA's if Melbourne is serious about becoming a cycling city (City of Melbourne, 2012). Further studies analysing the impact of this policy could provide future directions in this field, and help translate these local successes to other areas within Melbourne and beyond.

\section{Acknowledgements}

Many thanks to the Victoria Department of Transport for providing access to GIS formatted TravelSmart maps. This research was produced by $\mathrm{CP}$ as a part of a Master of Science degree at London School of Hygiene and Tropical Medicine, which was not externally funded. AG contributed to this research while funded by a post-doctoral 
fellowship from the National Institute of Health Research (NIHR). The views expressed in this paper are those of the authors and do not necessarily reflect those of the NIHR or the Department of Health

\section{References}

AUSTRALIAN BUREAU OF STATISTICS 2012a. Local Government Area factsheet. Accessed online 14/08/2013. http://www.abs.gov.au/websitedbs/d3310114.nsf/4a256353001af3ed4b2562bb001 21564/6b6e07234c98365aca25792d0010d730/\$FILE/Local Government Areas Fact Sheet.pdf.

AUSTRALIAN BUREAU OF STATISTICS 2012b. Statistical Area 2 factsheet. Accessed online 14/08/2013. http://www.abs.gov.au/websitedbs/d3310114.nsf/4a256353001af3ed4b2562bb001 21564/6b6e07234c98365aca25792d0010d730/\$FILE/Statistical Area Level 2 Fact Sheet .pdf.

AUSTRALIAN BUREAU OF STATISTICS 2013a. Australian Census 2011. Accessed online: $26 / 06 / 2023$. http://www.abs.gov.au.

AUSTRALIAN BUREAU OF STATISTICS 2013b. Regional population growth, Australia 2011-2012. Accessed online: 29/08/2013. http://www.abs.gov.au/ausstats/abs@.nsf/Latestproducts/3218.0Main Features5201112?opendocument $\&$ tabname $=$ Summary $\&$ prodno $=3218.0 \&$ issue $=2011$ $12 \&$ num $=\&$ view $=$.

AUSTRALIAN BUREAU OF STATISTICS 2013c. SEIFA 2011 technical paper. Accessed online: 31/08/2013. http://www.ausstats.abs.gov.au/ausstats/subscriber.nsf/0/22CEDA8038AF7A0DC A257B3B00116E34/\$File/2033.0.55.001 seifa 2011 technical paper.pdf. In: STATISTICS, A. B. O. (ed.).

AUSTRALIAN DEPARTMENT OF HEALTH 2010. Australian Department of Health and Aging. Healthy Spaces \& Places. Accessed online: 27/08/2013. http://www.healthyplaces.org.au/site/forum.php.

AUSTRALIAN DEPARTMENT OF INFRASTRUCTURE 2013. Active transportation policy. Accessed online: 28/08/2013.

http://www.infrastructure.gov.au/infrastructure/mcu/urbanpolicy/active_travel/ind ex.aspx.

BASSETT, D. R., JR., PUCHER, J., BUEHLER, R., THOMPSON, D. L. \& CROUTER, S. E. 2008. Walking, Cycling, and Obesity Rates in Europe, North America, and Australia. Journal of Physical Activity \& Health, 5, 795-814.

BICYCLE NETWORK 2013. The Bicycle Expenditure Index. Accessed online: 25/06/2013. https://http://www.bicyclenetwork.com.au/general/bike-futures/40830/.

BROACH, J., DILL, J. \& GLIEBE, J. 2012. Where do cyclists ride? A route choice model developed with revealed preference GPS data. Transportation Research Part a-Policy and Practice, 46, 1730-1740. 
BUEHLER, R. \& PUCHER, J. 2012. Cycling to work in 90 large American cities: new evidence on the role of bike paths and lanes. Transportation, 39, 409-432.

CAULFIELD, B., BRICK, E. \& MCCARTHY, O. T. 2012. Determining bicycle infrastructure preferences - A case study of Dublin. Transportation Research Part D-Transport and Environment, 17, 413-417.

CITY OF MELBOURNE 2012. City of Melbourne bicycle plan. Accessed online: 28/08/2013. http://www.melbourne.vic.gov.au/AboutCouncil/PlansandPublications/strategies/ Pages/Bikeplan.aspx.

CITY OF YARRA 2010. City of Yarra Bicycle Strategy. Accessed online: 28/08/2013. http://www.yarracity.vic.gov.au/Sustainable-transport/Bike-strategy/.

DE HARTOG, J. J., BOOGAARD, H., NIJLAND, H. \& HOEK, G. 2010. Do the Health Benefits of Cycling Outweigh the Risks? Environmental Health Perspectives, 118, 1109-1116.

DEKA, D. \& CONNELLY, M. 2011. Does Proximity to Activity-Inducing Facilities Explain Lower Rates of Physical Activity by Low-Income and Minority Populations? Transportation Research Record, 83-91.

DILL, J. 2009. Bicycling for Transportation and Health: The Role of Infrastructure. Journal of Public Health Policy, 30, S95-S110.

DILL, J., CARR, T. \& TRB 2003. Bicycle commuting and facilities in major US cities If you build them, commuters will use them. Pedestrians and Bicycles 2003: Safety and Human Performance.

DILL, J. \& HAGGERTY, B. 2009. Equity analysis of Portland's draft bicycle master plan. Portland State University, Center for Transportation Studies, 1-25.

FRASER, S. D. S. \& LOCK, K. 2011. Cycling for transport and public health: a systematic review of the effect of the environment on cycling. European Journal of Public Health, 21, 738-743.

FURIE, G. L. \& DESAI, M. M. 2012. Active Transportation and Cardiovascular Disease Risk Factors in U.S. Adults. American Journal of Preventive Medicine, 43, 621628.

GOODMAN, A. 2013. Walking, cycling and driving to work in the English and Welsh census 2011: Trends, socio-economic patterning and relevance to travel behaviour in general. plos $O N E$, 8.

GOODMAN, A., SAHLQVIST, S. \& OGILVIE, D. 2014. New Walking and Cycling Routes and Increased Physical Activity: One- and 2-Year Findings from the UK iConnect Study. American Journal of Public Health, 104, e38-e46.

GOODMAN, R. D., R. 2008. The best solution we never tried: Cycling and Transport Policy in Melbourne. World Transport Policy and Practice, 13, 8-17.

GORDON-LARSEN, P., BOONE-HEINONEN, J., SIDNEY, S., STERNFELD, B., JACOBS, D. R., JR. \& LEWIS, C. E. 2009. Active Commuting and Cardiovascular Disease Risk The CARDIA Study. Archives of Internal Medicine, 169, 1216-1223.

GOTSCHI, T. 2011. Costs and Benefits of Bicycling Investments in Portland, Oregon. Journal of Physical Activity \& Health, 8, S49-S58. 
HUY, C., BECKER, S., GOMOLINSKY, U., KLEIN, T. \& THIEL, A. 2008. Health, Medical Risk Factors, and Bicycle Use in Everyday Life in the Over-50 Population. Journal of Aging and Physical Activity, 16, 454-464.

KAMPHUIS, C. B. M., GISKES, K., KAVANAGH, A. M., THORNTON, L. E., THOMAS, L. R., VAN LENTHE, F. J., MACKENBACH, J. P. \& TURRELL, G. 2008. Area variation in recreational cycling in Melbourne: a compositional or contextual effect? Journal of Epidemiology and Community Health, 62, 890-898.

KRIZEK, K. J., BARNES, G. \& THOMPSON, K. 2009. Analyzing the Effect of Bicycle Facilities on Commute Mode Share over Time. Journal of Urban Planning and Development-Asce, 135, 66-73.

LINDSAY, G., MACMILLAN, A. \& WOODWARD, A. 2011. Moving urban trips from cars to bicycles: impact on health and emissions. Australian and New Zealand Journal of Public Health, 35, 54-60.

OGILVIE, D., BULL, F., POWELL, J., COOPER, A. R., BRAND, C., MUTRIE, N., PRESTON, J., RUTTER, H. \& ICONNECT, C. 2011. An Applied Ecological Framework for Evaluating Infrastructure to Promote Walking and Cycling: The iConnect Study. American Journal of Public Health, 101, 473-481.

PUCHER, J., BUEHLER, R., BASSETT, D. R. \& DANNENBERG, A. L. 2010a. Walking and Cycling to Health: A Comparative Analysis of City, State, and International Data. American Journal of Public Health, 100, 1986-1992.

PUCHER, J., DILL, J. \& HANDY, S. 2010b. Infrastructure, programs, and policies to increase bicycling: An international review. Preventive Medicine, 50, S106-S125.

PUCHER, J., GARRARD, J. \& GREAVES, S. 2011. Cycling down under: a comparative analysis of bicycling trends and policies in Sydney and Melbourne. Journal of Transport Geography, 19, 332-345.

ROJAS-RUEDA, D. D. N., A. TAINIO, M. NIEWENHUIJSEN, M. 2011. The health risks and benefits of cycling in urban environments compared with car use: health impact assessment study. British Medical Journal, 343.

SAHLQVIST, S., GOODMAN, A., SIMMONS, R. K., KHAW, K. T., CAVILL, N., FOSTER, C., LUBEN, R., WAREHAM, N. J. \& OGILVIE, D. 2013. The association of cycling with all-cause, cardiovascular and cancer mortality: findings from the population-based EPIC-Norfolk cohort. BMJ Open, 3, e003797.

SAHLQVIST, S. L. \& HEESCH, K. C. 2012. Characteristics of Utility Cyclists in Queensland, Australia: An Examination of the Associations Between Individual, Social, and Environmental Factors and Utility Cycling. Journal of Physical Activity \& Health, 9, 818-828.

SAUNDERS, L. G., J. PETTICREW, M. STEINBACH, R. ROBERTS, H. 2013. What are the health benefits of active travel? A systematic review of trials and cohort studies. Plos ONE, 8.

SHEPHARD, R. J. 2008. Is active commuting the answer to population health? Sports Medicine, 38, 751-758.

STEINBACH, R., GREEN, J., DATTA, J. \& EDWARDS, P. 2011. Cycling and the city: A case study of how gendered, ethnic and class identities can shape healthy transport choices. Social Science \& Medicine, 72, 1123-1130.

VICTORIA DEPARTMENT OF HEALTH 2013. Sustainable \& active transport policy. Accessed online 28/08/2013. 
http://www.health.vic.gov.au/sustainability/transport.htm.

VICTORIA DEPARTMENT OF TRANSPORT 2008. Walking and cycling: census analysis.

VICTORIA DEPARTMENT OF TRANSPORT 2012a. Cycling into the future policy. Accessed online: 28/08/2013. http://www.transport.vic.gov.au/_data/assets/pdf_file/0011/83981/Cyclingstrategy-Cycling-into-the-Future-Dec-2012.pdf.

VICTORIA DEPARTMENT OF TRANSPORT 2012b. TravelSmart travel planning. Accessed online: 16/06/2013. http://www.transport.vic.gov.au/projects/travelsmart.

WOODCOCK, J., EDWARDS, P., TONNE, C., ARMSTRONG, B. G., ASHIRU, O., BANISTER, D., BEEVERS, S., CHALABI, Z., CHOWDHURY, Z., COHEN, A., FRANCO, O. H., HAINES, A., HICKMAN, R., LINDSAY, G., MITTAL, I., MOHAN, D., TIWARI, G., WOODWARD, A. \& ROBERTS, I. 2009. Health and Climate Change 2 Public health benefits of strategies to reduce greenhouse-gas emissions: urban land transport. Lancet, 374, 1930-1943.

WOODCOCK, J., FRANCO, O. H., ORSINI, N. \& ROBERTS, I. 2011. Non-vigorous physical activity and all-cause mortality: systematic review and meta-analysis of cohort studies. International Journal of Epidemiology, 40, 121-138.

WOODCOCK J., T. M., CHESHIRE J., O'BRIEN O., GOODMAN A. 20142014. Health effects of the London bicycle sharing system: health impact modelling study. British Medical Journal, 348.

WOODWARD, A. 2013. Cycling and Health: Five Myths. London School of Hygiene \& Tropical Medicine, Transport and Health Seminar Series.

YANG, L., SAHLQVIST, S., MCMINN, A., GRIFFIN, S. J. \& OGILVIE, D. 2010. Interventions to promote cycling: systematic review. British Medical Journal, 341. 


\section{Supplementary Information}

\section{Supplementary Figure S1: Location of inner Melbourne, within Victoria and within} Australia

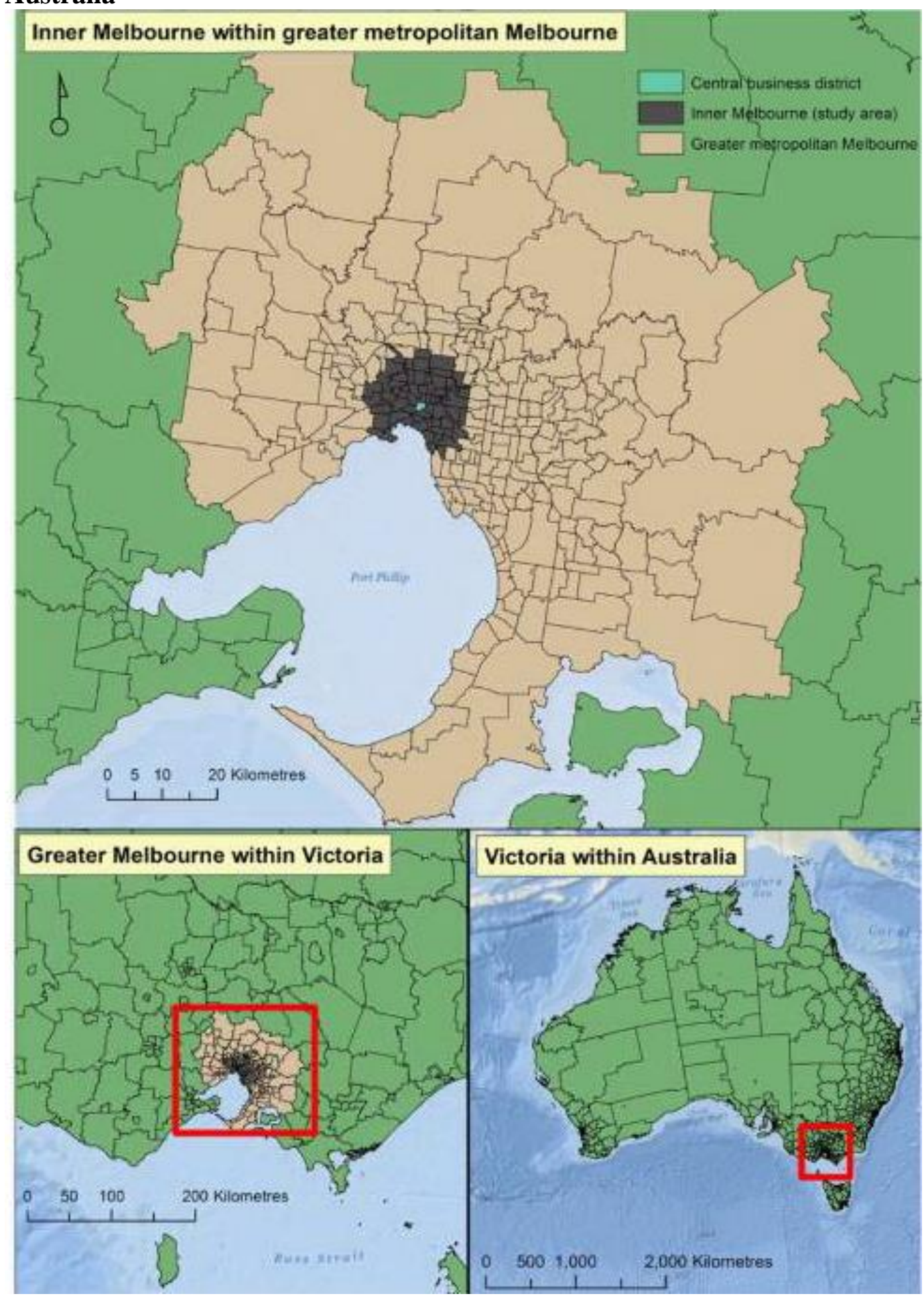


Supplementary Figure S2: Study area, and selected key SA2 areas

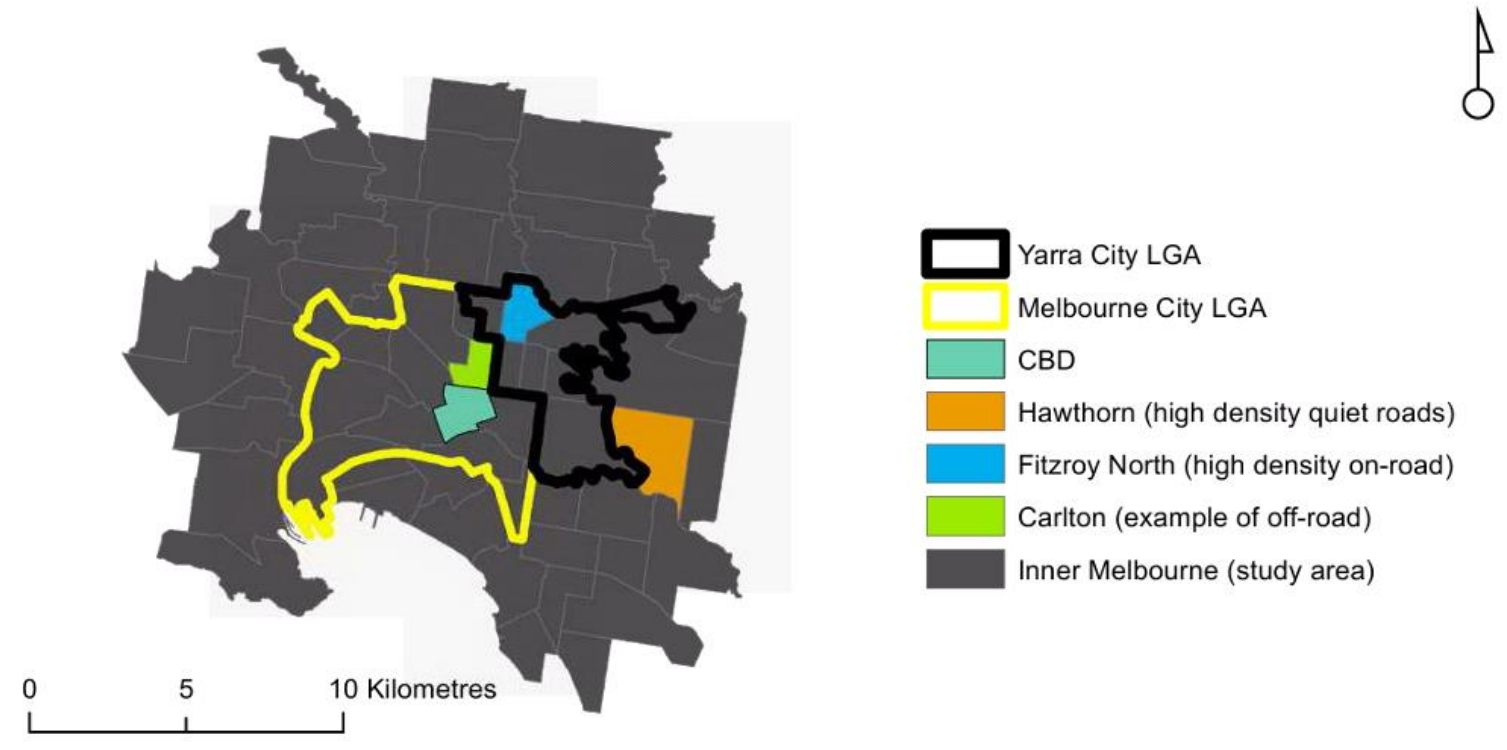

LGA=Local Government Authority; CBD = Central Business District 
Supplementary Figure S3: Examples of the three infrastructure types in Melbourne

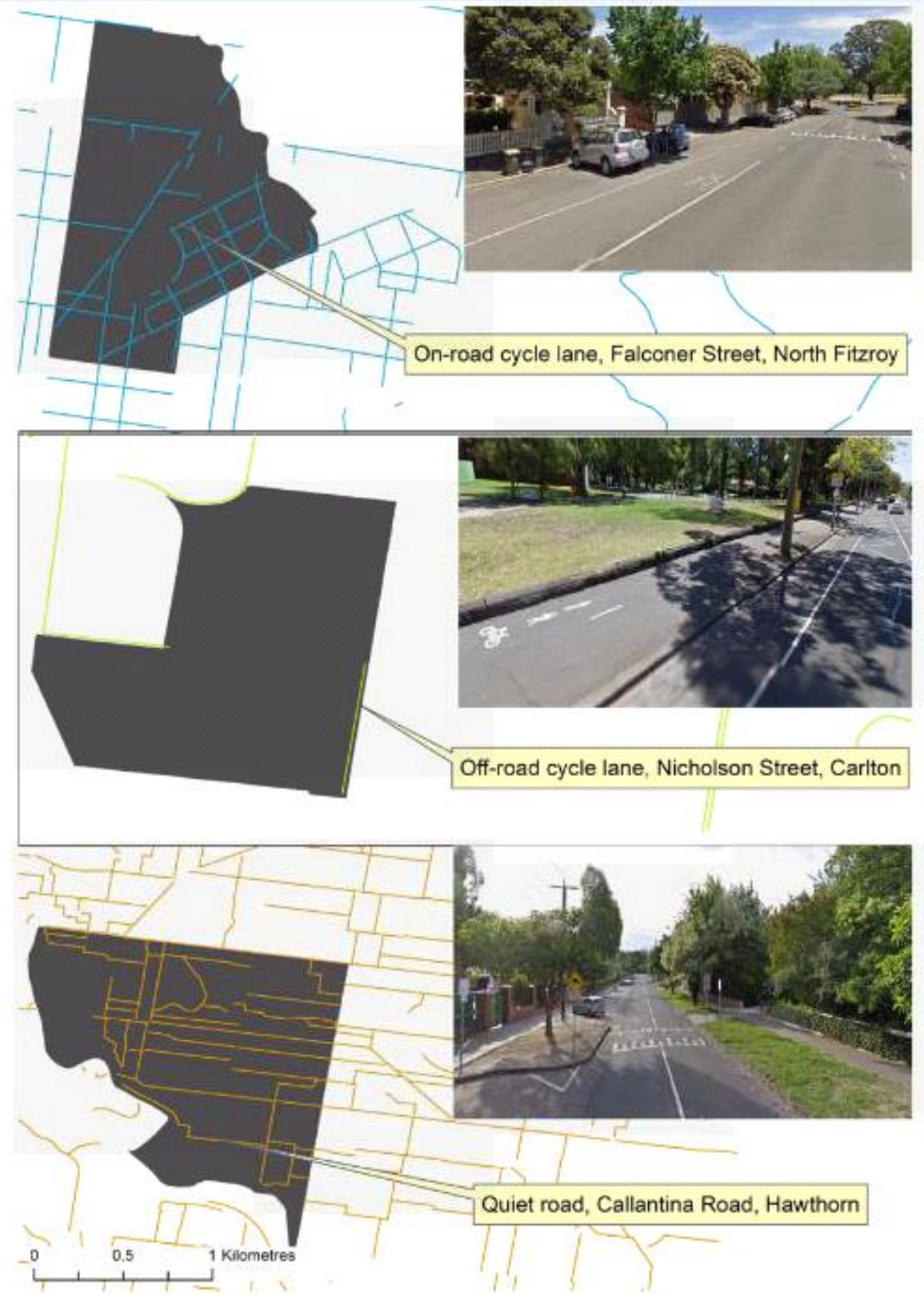


Supplementary Figure S4: Prevalence of cycle commuting across inner Melbourne

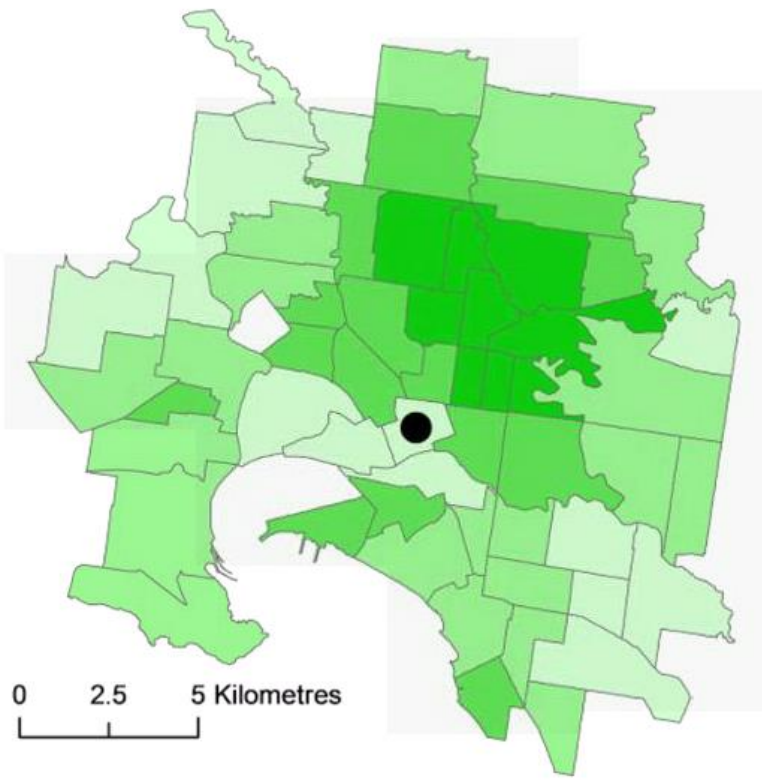

Supplementary Figure S5: Distribution of socio-economic advantage across inner Melbourne

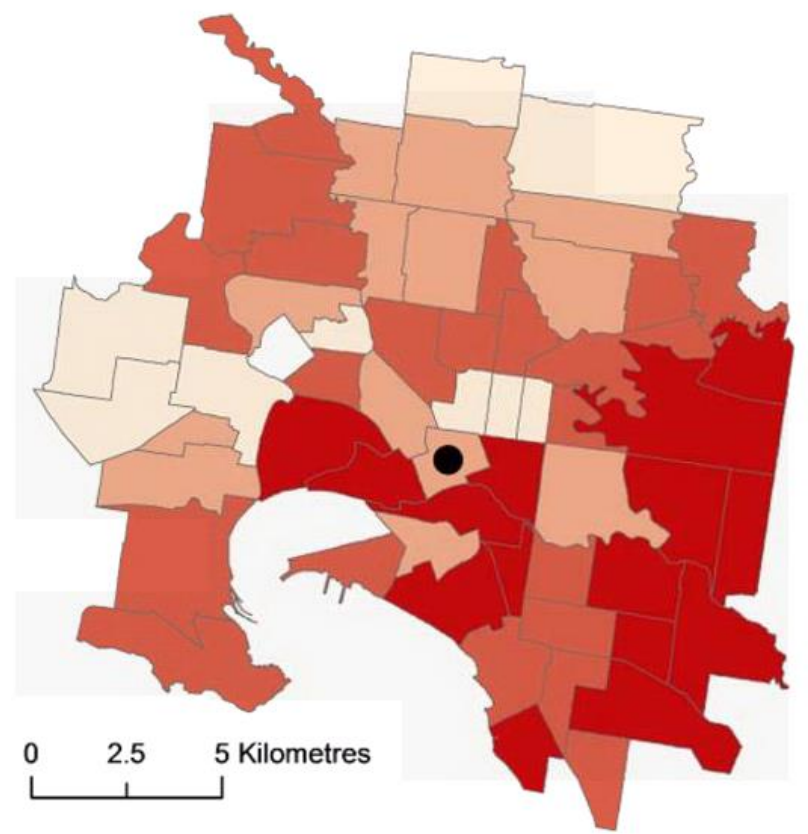

\section{SEIFA 2011 percentile}

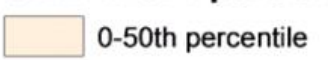

50th to 75 th percentile

75th to 90 th percentile

90th to 100 th percentile

SEIFA = 'Socioeconomic Indicators For Areas'. Higher percentage values correspond to more affluent areas. 
Supplementary Figure S6: Distribution of cycling infrastructure across inner Melbourne
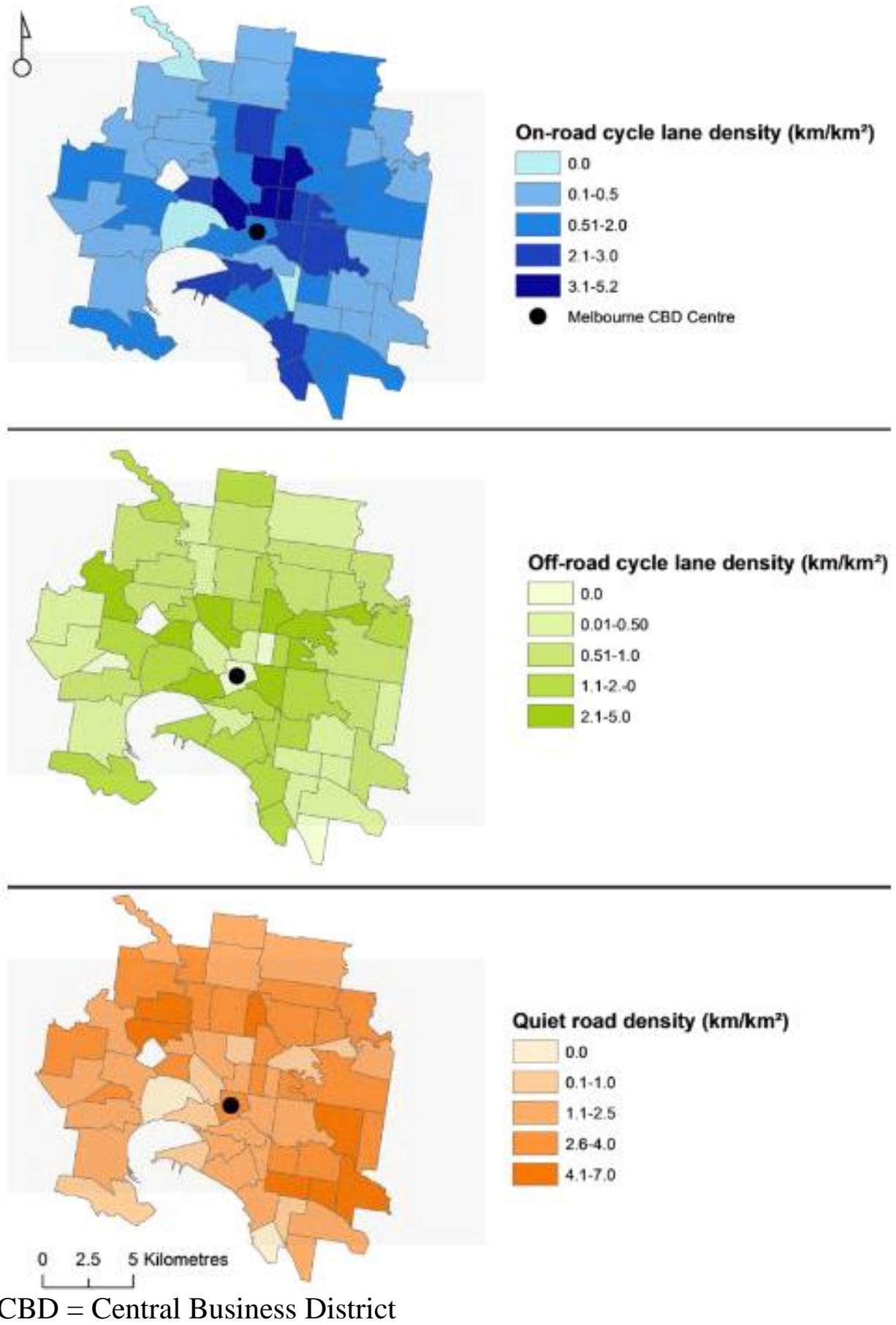